\title{
Characterization and Biocontrol Ability of Fusion Chitinase in Escherichia coli Carrying Chitinase cDNA from Trichothecium roseum
}

\author{
Hongyu Pan ${ }^{\mathrm{a}, \mathrm{b}}$, Yi Wei ${ }^{\mathrm{b}, \mathrm{c}}$, Furong Xin ${ }^{\mathrm{c}}$, Mingguo Zhou ${ }^{\mathrm{a}}$, and Shihong Zhang,* \\ a College of Plant Protection, Nanjing Agricultural University, Nanjing/Jiangsu 210095, \\ China \\ b College of Plant Science, Jilin University, Changchun/Jilin 130062, China. \\ Fax: +86-431-6758762. E-mail: zhang_sh@jlu.edu.cn \\ c Shandong Cotton Research Center, Jinan/Shandong 250100, China \\ * Author for correspondence and reprint requests \\ Z. Naturforsch. 61c, 397-404 (2006); received September 19/November 23, 2005
}

The antifungal mechanism of mycoparasitic fungi involves fungal cell wall degrading enzymes such as chitinases. Trichothecium roseum is an important mycoparasitic fungus with significant antifungal ability, but studies on chitinases of $T$. roseum were poor. Here, we report a novel chitinase cDNA isolated from $T$. roseum by PCR amplification based on conserved chitinase sequences. Southern blot analysis suggested that a single copy of the gene exists in the genome of $T$. roseum. The deduced open reading frame of 1,143 nucleotides encodes a protein of 380 amino acids with a calculated molecular weight of $41.6 \mathrm{kDa}$. The fusion chitinase expressed in Escherichia coli has been purified by single-step chromatography. It has a pI of pH 5.4 and expresses a thermal stability, but is insensitive to $\mathrm{pH}$ in a broad $\mathrm{pH}$ range. According to expectation, E. coli efficiently yielded a high amount of active chitinase. Remarkably, the fusion chitinase offered high antifungal activity.

Key words: Fusion Chitinase, Characterization and Biocontrol Ability, Trichothecium roseum

\section{Introduction}

Biological control of plant pathogens is a potential alternative to the use of chemical pesticides (Chet, 1994). The famous biological control agent Trichoderma is a rather specific and effective mycoparasite of various soil-borne plant pathogenic fungi in greenhouse and field conditions. So far, the extensive studies exploring the mechanisms involved in biological control were performed. Generally, the classical mycoparasitic process involves five aspects (Carsolio et al., 1994). Among them, the production of cell wall-degrading enzymes, such as chitinase is very important. Chitinase production of mycoparasites is correlated with biological control of some fungal diseases (Schirmbock et al., 1994), because chitin is a major structural component of cell wall in many plant pathogens. To date, more than ten chitinase-encoding genes have been cloned and characterized from Trichoderma spp. (Hayes et al., 1994; Kim et al., 2002). Furthermore, transgenic plants containing the chitinase gene (ech42) and transformed Trichoderma strains carrying multiple copies of prb1 showed a higher resistance to several fungi (Flores et al., 1997).
Trichothecium roseum is another important mycoparasitic fungus and has been used as a potential agent for controlling a number of plant pathogens. The first report was on its biocontrol application against most plant pathogens causing storage rot of onions (Rod, 1984). Since then, several studies on its biological control ability were reported. For example, Urbasch (1985) and Huang and Kokko (1993), respectively, isolated T. roseum and tested its antifungal activity against plant pathogens such as Pestalotia funereal and Sclerotinia sclerotiorum; Kumar and Jha (2002) isolated T. roseum as well and designed trial controlling soybean rust by using the fungus. Exhilaratingly, they obtained a very successful biological effect. In addition, effective inhibition of plant pathogens, like Fusarium oxysporum, Bipolaris oryzae, Alternaria spp., Ganoderma spp., Rhizoctonia solani, Curvularia spp., and Pyricularia oryzae, has been studied for T. roseum as well (Balasubramanian et al., 2003). Culture filtrates of $T$. roseum have confirmed the effective inhibition of a broad spectrum of plant pathogens, though substances in the culture filtrates are very complex and unclear.

Chitinases from $T$. roseum, in comparison with Trichoderma spp., were poorly studied, though in- 
terest has slowly increased due to the potential role as control agent for plant pathogenic fungi. The studies on characterization of purified chitinase from $T$. roseum have been reported recently (Li et al., 2004). A high level chitinase activity appeared in a broad range of $\mathrm{pH} 4.0-7.0$, at $40^{\circ} \mathrm{C}$. Just as ThEn-42 (De La Cruz et al., 1992), it offered efficacious inhibition of some plant pathogens tested, particularly of Verticillium dahliae. However, it is difficult to develop further studies of this chitinase for two reasons: firstly, the expression of $T$. roseum was poor and inefficient, and secondly, the purification procedure was very complex and tedious. Therefore, cloning and over-expression of the chitinase gene are urgent. Here, we describe the cloning of chitinase from $T$. roseum and expression in E. coli. Properties and potential application of the fusion protein are evaluated.

\section{Materials and Methods}

Fungus strains, plasmids, and culture conditions

Trichothecium roseum s24 isolated from Shandong cotton filed is part of a native strain collection held at Jilin University, Changchun/Jilin, China. In order to extract genomic DNA and total RNA, this strain was inoculated $\left(10^{5}-10^{6}\right.$ conidia per $\mathrm{ml}$ ) in medium according to Schirmbock et al. (1994) (0.68 g KH${ }_{2} \mathrm{PO}_{4}, 0.87 \mathrm{~g} \mathrm{~K}_{2} \mathrm{HPO}_{4}, 0.2 \mathrm{~g} \mathrm{KCl}$, $1 \mathrm{~g} \mathrm{NH}_{4} \mathrm{NO}_{3}, 0.2 \mathrm{~g} \mathrm{MgSO}_{4} \cdot 7 \mathrm{H}_{2} \mathrm{O}, 0.2 \mathrm{~g} \mathrm{CaCl}_{2}$, pH 5.0) supplemented with $1 \mathrm{~g}$ glucose. Mycelia were grown on a rotary shaker $(200 \mathrm{rpm})$ at $25^{\circ} \mathrm{C}$. After $2 \mathrm{~d}, 30 \mathrm{~g}$ colloidal chitin were added to the broth medium. Incubation was continued for an additional $6 \mathrm{~d}$. Then, mycelia were collected by filtration, washed with sterile water, frozen in liquid nitrogen, and then stored at $-80^{\circ} \mathrm{C}$. Strain JM109 of E. coli was transformed with recombinant plasmids and cultured in LB broth to select transformants. pET22b (+) (Novagen) was used as the cloning and expression vector.

\section{DNA/RNA manipulation}

Total genomic DNA from $T$. roseum was extracted followed a standard method (Hohn and Desjardins, 1992). Total RNA from T. roseum s24 was extracted according to the method of Jones et al. (1985) with a slight modification. In order to synthesize cDNA, poly (A) mRNA was isolated and purified by using mRNA Purification-Kit (Stratagene). DNA probes were labeled with Random Primer Labeling Kit (TaKaRa).

\section{Cloning of the chitinase gene cDNA from}

\section{T. roseum}

A pair of degenerated oligonucleotide primers that code for conserved amino acid sequences was designed as follows: $5^{\prime}-(\mathrm{C} / \mathrm{G}) \mathrm{CA}(\mathrm{G} / \mathrm{A})(\mathrm{C} / \mathrm{A})(\mathrm{T} /$ $\mathrm{C})(\mathrm{C} / \mathrm{G})(\mathrm{A} / \mathrm{C}) \mathrm{G}(\mathrm{T} / \mathrm{C}) \mathrm{TC}(\mathrm{C} / \mathrm{T})(\mathrm{T} / \mathrm{A})(\mathrm{T} / \mathrm{C})(\mathrm{C} / \mathrm{T})$ TC $(\mathrm{A} / \mathrm{C})$ CCAACTGG-3'(Up), 5' $-(\mathrm{C} / \mathrm{A} / \mathrm{T})(\mathrm{A} / \mathrm{T})$ (G/C/T)GTA(G/C)(C/T)CCC(A/G)AA(T/A/C) ACCGTTCT(C/G)CCA-3' (Dp). PCR was carried out for 35 cycles $\left(1 \mathrm{~min}\right.$ at $94{ }^{\circ} \mathrm{C}, 1 \mathrm{~min}$ at $50^{\circ} \mathrm{C}$, and 2 min at $72{ }^{\circ} \mathrm{C}$ ) with total DNA fragments as templates. The PCR products were sequenced. Based on the DNA sequence and as comparison to the endochitinase gene cDNA (ThEn-42) from Trichoderma spp., A1 (5'-CCGCTGAGAAGAT CATCCTCG-3'), S1 (5'-TACGCTGGAGAAGG AGGACCA-3') and A2 (5'-GAGGGCAGCTGG GAGAACGGT-3'), S2 (5'-TAGGTGTCACCGC TGTAGAC- $3^{\prime}$ ) were designed as two pairs of RACE primers. The two end sequences of the target gene were obtained according to the RACE method of Frohman et al. (1988), but with some modifications. First-strand cDNA fragments were synthesized according to manufacturer's recommendations by using an improved oligo-dT11 primer [5'-CAGTGCT11 (A/G/C)-3',5'-end-phosphorylated]. 5'-End Full RACE Core Set (TaKaRa) was used as follows: synthesized cDNA (hybrid DNA-RNA) was digested with RNase $\mathrm{H}$ (DNase free). Subsequently, circularization of single-stranded cDNA was carried out with $\mathrm{T}_{4}$-RNA ligase. First PCR products were obtained by using the circle strand cDNA as template and A1and S1 primers. DNA amplification by nested PCR was performed with A2 and S2 as primers. Two ends of the nested PCR products were sequenced. The ORF fragments of chitinase cDNA were amplified by using RT-PCR with a pair of specific primers (OF, 5'-acgaattcgATGTTGGGCTTCTCC-3'; OD, 5'-gtctcgagAAGTATGAACAGCGG-3' the italic small letters mentioned are convenient for the next DNA manipulation). The PCR products were completely digested with EcoRI and XhoI and ligated into pET22b $(+)$ digested by using the EcoRI and XhoI too. The ligation product was electroporated in E. coli JM109. Transformants were selected in LB agar supplemented with ampicillin $(100 \mu \mathrm{g} / \mathrm{ml})$.

\section{Genomic Southern blot analysis of the cloned chitinase gene}

Total genomic DNA from $T$. roseum was digested to completion with the following restriction 
enzymes: BamHI, EcoRI, and XbaI, electrophoresed on $0.8 \%$ agarose gel and blotted onto $\mathrm{Hy}$ bond $\mathrm{N}$ membrane (Amersham) using capillary transfer. The cloned chitinase gene fragments (ORF) above were used as probes. Southern blot was performed under high-stringency conditions.

\section{Production and purification of chitinase}

E. coli JM109 was grown at $30^{\circ} \mathrm{C}$ till the culture reached an $\mathrm{OD}_{600}$ of 0.4 . Incubation was continued for $4 \mathrm{~h}$ after adding IPTG as inducer. Cells were harvested by centrifugation, washed, and crushed with glass beads. Total proteins were dissolved in solution I [20 mm $\mathrm{Na}_{2} \mathrm{HPO}_{4}(\mathrm{pH}$ 7.2), $0.5 \mathrm{~mm} \mathrm{NaCl}$. A fraction of soluble proteins was obtained after centrifugation at $4{ }^{\circ} \mathrm{C}$ for $30 \mathrm{~min}$ at $14,000 \times g$ and was loaded onto a $\mathrm{Ni}^{2+}$-NTA-agarose column ( $3 \mathrm{ml}$ bed volume). The column was successively washed with binding buffers containing $100 \mathrm{~mm}$ imidazole, and then the immobilized proteins were eluted with $500 \mathrm{~mm}$ imidazole. Histagged chitinase was dialysed against solution I and stored at $4{ }^{\circ} \mathrm{C}$ for further use. Protein concentrations after purification were determined by using bovine serum albumin (BSA) as the standard (Bradford, 1976). The efficiency of this purification procedure was checked by SDS-PAGE.

\section{Chitinase activity assay}

Chitinase activity was evaluated by using 4methylumbelliferyl-D- $N, N^{\prime}, N^{\prime \prime}$ - triacetylchitotriose [4-MU-(GlcNAc) $)_{3}$ ] (Sigma). A total volume of 300 $\mu \mathrm{l}$ reaction system was prepared as follows: $250 \mu \mathrm{l}$ of reaction buffer, $30 \mu \mathrm{l}$ of sample, and $20 \mu \mathrm{l}$ of substrate $(0.1 \mu \mathrm{g} / \mu \mathrm{l})$ were mixed and incubated at $40{ }^{\circ} \mathrm{C}$ for $4 \mathrm{~h}$; the reaction was terminated by adding 1 volume of $0.2 \mathrm{M} \mathrm{Na}_{2} \mathrm{CO}_{3}$. Chitinase activity was measured by the mean fluorescence estimated in a Turner fluorometer (model 450; 340-nm interference filter and 415-nm cut filter). One unit of chitinase activity was defined as the amount of enzyme required to release $1 \mu \mathrm{mol}$ of 4-methylumbelliferone in $60 \mathrm{~min}$. Specific activity was expressed as units per milligram of protein.

\section{SDS-PAGE and activity staining of chitinase}

Sodium dodecyl sulfate-polyacrylamide gel electrophoresis (SDS-PAGE) was performed according to Laemmli (1970): Samples were mixed with an equal volume of 2 times Laemmli sample buffer containing $1 \%$ Triton $\mathrm{X}-100$, and the mixtures were heated at $60{ }^{\circ} \mathrm{C}$ for $5 \mathrm{~min}$. The gel was stained with $0.05 \%$ Coomassie brilliant blue R-250 for identification of the purified protein. In order to identify the chitinase activity, another half of the gel running in the mean time was transferred into the washing buffer [ $1 \%$ casein, 2 mм EDTA, $40 \mathrm{~mm}$ tris(hydroxymethyl) aminomethane- $\mathrm{HCl}$ (Tris- $\mathrm{HCl}, \mathrm{pH}$ 8.0)] for the removal of SDS from the gel and the renaturation of the chitinase. After several washings in double distilled water and sodium acetate buffer ( $\mathrm{pH} 4)$, the gel was covered with $1 \%$ low melting-point agarose supplemented with $0.2 \mathrm{~mm}$ 4-MU-(GlcNAc) $)_{3}$ in $100 \mathrm{~mm}$ potassium phosphate buffer ( $\mathrm{pH}$ 6.0). Gel was inspected for fluorescent bands under ultraviolet light after incubation at $40{ }^{\circ} \mathrm{C}$ for $120 \mathrm{~min}$ (Tronsmo and Harman, 1993).

\section{Effects of $p H$ value, temperature, and metal ions on the purified fusion chitinase}

The optimal $\mathrm{pH}$ value of the chitinase activity of the purified fusion chitinase was assayed by the following buffers: sodium lactate at $\mathrm{pH} 3.0$ and 3.5; sodium acetate at $\mathrm{pH}$ 4.0, 4.5 and 5.5; potassium phosphate at $\mathrm{pH} 6.0,6.5,7.0$, and 7.5 ; Tris- $\mathrm{HCl}$ at $\mathrm{pH}$ 8.0. The optimal temperature of the chitinase activity was assayed in microplates placed at 20 to $80^{\circ} \mathrm{C}$ in potassium phosphate buffer ( $\mathrm{pH} \mathrm{6.0)}$ ). The enzyme thermal stability was determined after preincubation in the temperature range of 20 to $80^{\circ} \mathrm{C}$ for $5 \mathrm{~h}$ without the substrate, then the residual chitinase activity was checked under standard assay conditions. To determine the influence of metal ion on chitinase activity, $\mathrm{Mg}^{2+}, \mathrm{Cu}^{2+}, \mathrm{Ca}^{2+}$, $\mathrm{Zn}^{2+}, \mathrm{Mn}^{2+}, \mathrm{Ba}^{2+}, \mathrm{Fe}^{2+}, \mathrm{Hg}^{2+}, \mathrm{Co}^{2+}$, or $\mathrm{Ag}^{+}$were tested, respectively. Each metal ion was added at a final concentration of $1 \mathrm{~mm}$ in potassium phosphate buffer ( $\mathrm{pH}$ 6.0). All the reaction mixtures contained chitinase fraction and 4-MU-(GlcNAc) $)_{3}$ as the substrate.

\section{Isoelectrofocusing (IEF) of the fusion chitinase}

PhastGel IEF 3-9 was chosen to identify the pI of fusion chitinase. The IEF procedure was carried out according to the Phast-System User's Manual. Standard pI marker proteins (Pharmacia) contained the following members: trypsinogen-9.3, lentil lectin basic subunit-8.65, lentil lectin middle subunit-8.45, lentil lectin acidic subunit-8.15, myoglobin basic subunit-7.35, myoglobin acidic subunit-6.85, human carbonic anhydrase B-6.55, bo- 
vine carbonic anhydrase B-5.85, $\beta$-lactoglobulin A-5.20, soybean trypsin inhibitor-4.55, and amyloglucosidase-3.50.

\section{Antifungal activity of the purified fusion chitinase}

To check if the chitinase had antifungal activity, several economically important plant pathogens were selected: Alternaria alternata, Alternaria solani, Fusarium oxysporum, Magnaporthe grisea, Verticillium dahliae, Botrytis cinerea. In order to obtain enough spores, all pathogens were isolated from newly infected organisms and grown in potato dextrose agar (PDA). After sporulation, spores were collected, washed three times using sterile water, and then suspended in $0.1 \%(\mathrm{w} / \mathrm{v})$ glucose. To examine the effects on spore germination, spores could be used directly; to examine the influence on elongation of germ tube, spores should be preincubated in normal conditions, till germ tube appeared. $50 \mu \mathrm{l}$ of the fungal spore (germinated or not) conidial suspension were mixed with or without serial diluted amounts of purified chitinase in the wells of sterile depression slides, and incubated at $25^{\circ} \mathrm{C}$ for $10 \mathrm{~h}$. Influence results were investigated under a light microscope at $100 \times$ magnification.

\section{Results and Discussion}

A 977 bp DNA fragment was obtained from $T$. roseum by PCR amplification following the experiment procedures. Sequencing of the DNA (GenBank accession number, AY550119) showed that it shares $71 \%$ similarity with the ech 42 of $T$. harzianum (Garcia et al., 1994). Southern blot analysis suggested that a single copy of the gene exists in the genome of T. roseum (Fig. 1). So, It was reasonable to regard it as a chitinase gene fragment.

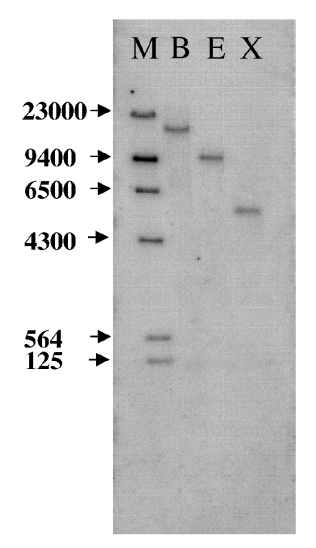

Fig. 1. Genomic Southern blot analysis of the chitinase gene. Southern blot hybridization was done using a random primer probe kit as a probe to DNA digested with BamHI (lane B), EcoRI (lane E), XbaI (lane X); lane $\mathrm{M}$ contains a molecular size marker (unit, bp).
Based on the amplified DNA and the cDNA sequence of ech 42 , we successfully obtained the cDNA information of two ends of target cDNA. Thus, a pair of specific primers (OF, OD) could be very easily designed, and we cloned the chitinase cDNA with standard RT-PCR method. The deduced open reading frame (ORF) of 1,143 nucleotides encodes a protein of 380 amino acids with a calculated molecular weight of $41.6 \mathrm{kDa}$ (Fig. 2). Remarkably, the method we used was different from the classic RACE (Frohman et al., 1988). From the result, this is an efficacious and economical way to clone cDNA.

The fusion protein with more chitinase activity has been purified to SDS-PAGE homogenous (Fig. 3). The molecular weight of the chitinase is $46.2 \mathrm{kDa}$. $15.4 \mathrm{mg}$ (total activity, 23,500.4 U) pure chitinase have been obtained per liter medium. IEF showed that the isoelectric point (pI) of fu-

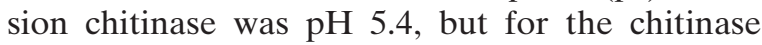
produced by T. roseum it was $\mathrm{pH} 5.1$ (Fig. 4). The purified chitinase has an optimal activity around pH 6, so it revealed the enzyme was fairly stable in a $\mathrm{pH}$ range of 4.0 to 7.0 (Fig. 5A). Under standard assay conditions ( $\mathrm{pH}$ 6.0) except for temperature, the maximum activity was observed at $40^{\circ} \mathrm{C}$ (Fig. 5B). After preincubation in the temperature range of 40 to $45^{\circ} \mathrm{C}$ for $5 \mathrm{~h}$, the fusion chitinase retained almost its full activity. Even temperature at $55^{\circ} \mathrm{C}$, it also retained $65 \%$ activity. However, the chitinase produced by $T$. roseum almost lost enzyme activity at temperatures above $45^{\circ} \mathrm{C}$ (Fig. 5C). The result indicated that the fusion enzyme obtained a moderate thermal stability. Based on the similar properties of both chitinases, we think that they probably belong to the same one. The difference may be caused by the pET-22b (+) vector, if considering a redundant part of $4.6 \mathrm{kDa}$ in the fusion protein.

Addition of selected metal ions to the reaction mixtures did not affect the chitinase (fusion chitinase or chitinase from $T$. roseum) activity appreciably, except $\mathrm{Hg}^{2+}$. The metal ion $\mathrm{Hg}^{2+}$ inhibited both chitinases activity by similar percentage (Table I). This agrees with the results in related researches on inhibition of chitinases, and supports that chitinase inhibition by $\mathrm{Hg}^{2+}$ is a general characteristic of the chitinase group.

In our examination, spore germination and germ tube elongation of the tested fungi were significantly inhibited by the chitinase as compared with the phosphate buffer control (Table II). This 


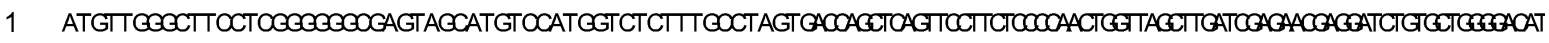

$1 M L G F L G G R \vee A C P W S L C L V T S S V P S P C L V S L I E N E D L C W G$

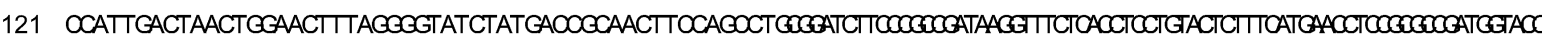

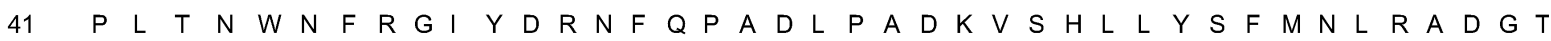

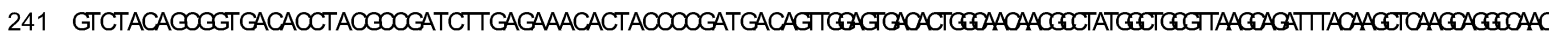

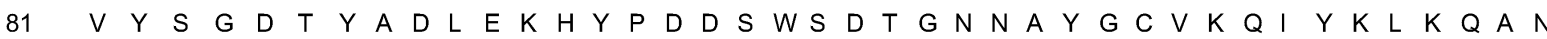

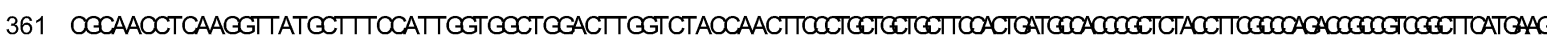

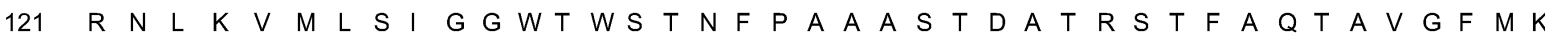

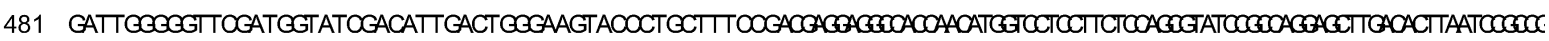
161 D W G F D G I D I D W E V P C F P T R R P P T W S S F S S V S A R S L T L N P F

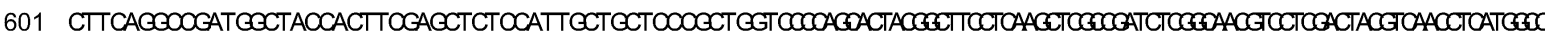
201 L $Q$ A $D$ G

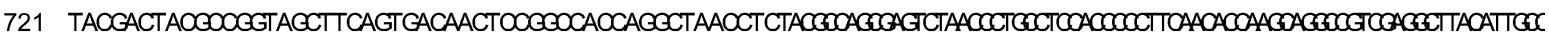
241 Y $D$ P

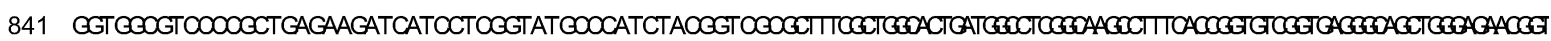
281 G G V P A E K I I L G M P I Y GR A F A G T D G L G K P F T G V GE GSWENG

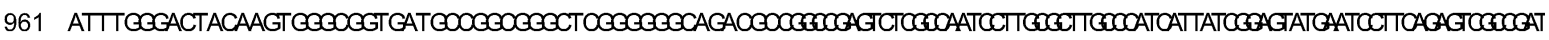

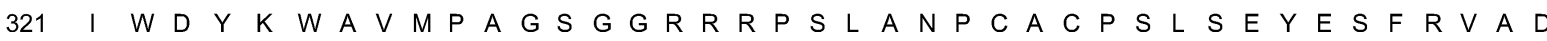

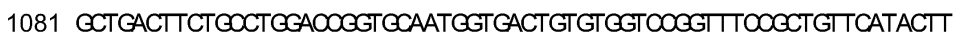

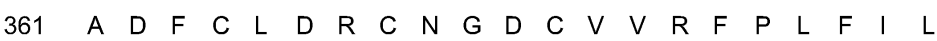

Fig. 2. cDNA sequence (ORF) and deduced amino acid sequence of the T. roseum chitinase.

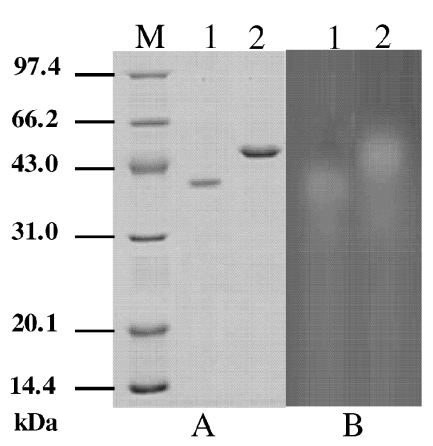

Fig. 3. SDS-PAGE of purified chitinase of T. roseum s24 and fusion chitinase. (A) Coomassie brilliant blue R-250 staining. (B) Activity staining. Lanes: M, standard marker proteins; 1 , purified chitinase from T. roseum; 2, fusion chitinase expressed in E. coli.

antifungal activity is consistent with what we have studied on $T$. roseum. Therefore, the over expressed fusion chitinase is promising to be utilized in practice.

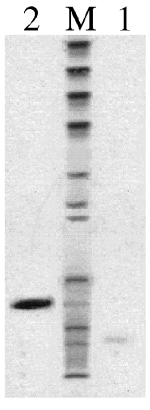

T. roseum is a very useful fungus, not only in agriculture as a biological control agent (Balasubramanian et al., 2003), but also in medicine for the treatment of human diseases (Sesan, 1986). At the same time, it is also a notorious fungus for associations between the first trichothecene isolated from the fungus (Freeman and Morrison, 1949) and outbreaks of human diseases caused by mycotoxin 

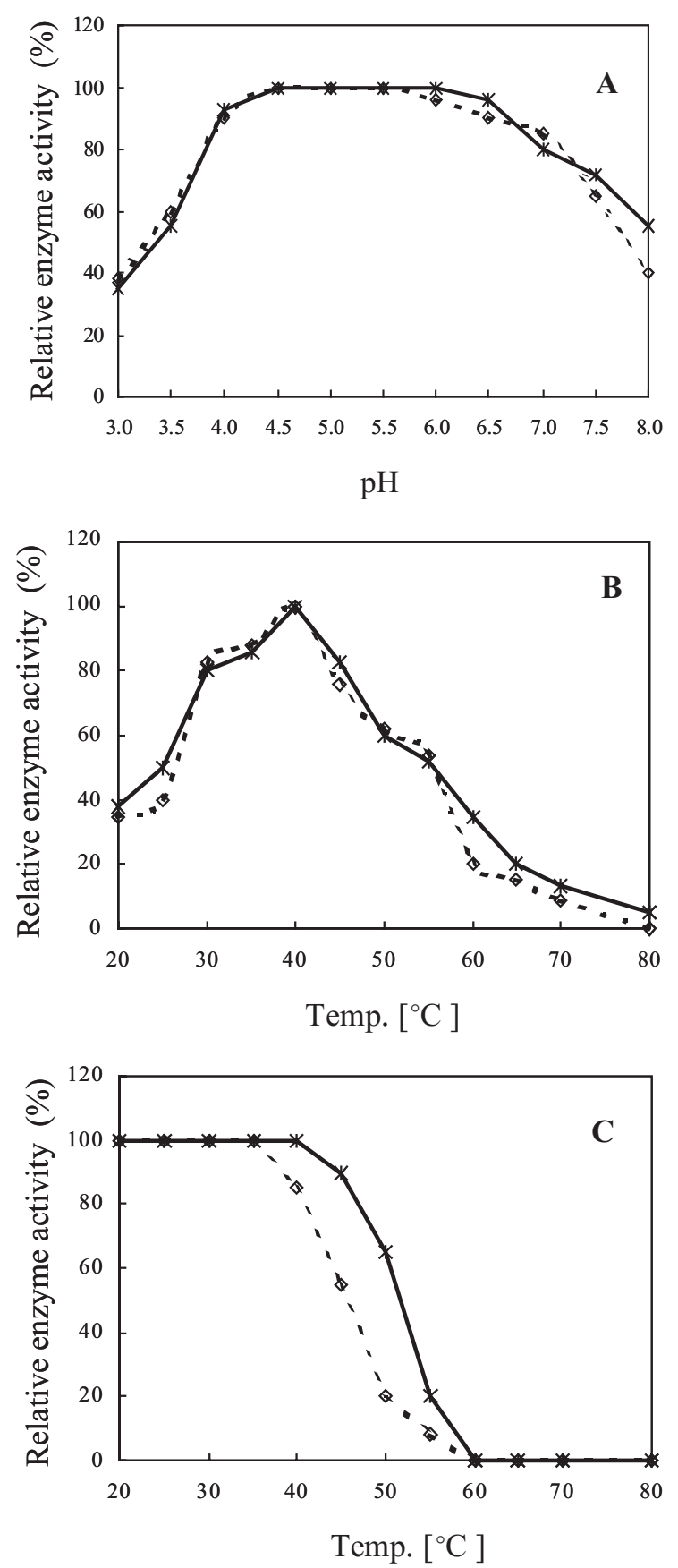

Fig. 5. The optimal $\mathrm{pH}$, optimal temperature and thermal stability of the purified chitinase. The chitinase activity was detected at $40{ }^{\circ} \mathrm{C}$ for measuring the optimal $\mathrm{pH}$ value (A), at $\mathrm{pH} 6.0$ for measuring the optimal temperature (B), or at $40^{\circ} \mathrm{C}, \mathrm{pH} 6.0$ after the enzyme was incubated at 20 to $80^{\circ} \mathrm{C}$ for $5 \mathrm{~h}$ with $4-\mathrm{MU}-(\mathrm{GlcNAc})_{3}$ as the substrate (C). Solid line, activity of the fusion chitinase; broken line, activity of chitinase from T. roseum.
Table I. Effects of metal ions on chitinases in potassium phosphate buffer ( $\mathrm{pH}$ 6.0).

\begin{tabular}{lcc}
\hline Metal ion & \multicolumn{2}{c}{ Residual activity of chitinase $(\%)$} \\
\cline { 2 - 3 } & $\begin{array}{c}\text { Chitinase from } \\
\text { T. roseum }\end{array}$ & Fusion chitinase \\
\hline Phosphate buffer & 100 & 100 \\
$\mathrm{Mg}^{2+}$ & 95 & 97 \\
$\mathrm{Cu}^{2+}$ & 101 & 98 \\
$\mathrm{Ca}^{2+}$ & 108 & 103 \\
$\mathrm{Zn}^{2+}$ & 98 & 96 \\
$\mathrm{Mn}^{2+}$ & 87 & 91 \\
$\mathrm{Ba}^{2+}$ & 92 & 96 \\
$\mathrm{Fe}^{2+}$ & 94 & 88 \\
$\mathrm{Hg}^{2+}$ & 58 & 60 \\
$\mathrm{Co}^{2+}$ & 100 & 99 \\
$\mathrm{Ag}^{+}$ & 97 & 93 \\
\hline
\end{tabular}

The values are means of data from two repetitions of the experiment, with three replicates per treatment.

(Joffe, 1974). In addition, Lorito et al. (1998) pointed out that a full-scale application of fungal biological control agents in commercial agriculture should be delayed because of the inconsistent results obtained by introducing these complex microorganisms into the dynamic environment. Utility of antifungal substances isolated from $T$. roseum is a significant aspect in biological control, but the yield by mycoparasites is relatively not enough. As a result, expression of chitinase gene from mycoparasites is a good way. Moreover, the fusion protein, with properties of a broad range of $\mathrm{pH}$ value and a moderate thermal stability, has a significant antifungal activity against a number of plant pathogens (data not shown). So further studies will open up at both aspects: (i) application of the fusion chitinase, (ii) in vivo analysis of biological function by disruption of the chitinase gene.

\section{Acknowledgements}

We are indebted to Dr. H. Wang and X. Men for technical assistance with IEF analyses and critical reading of the manuscript. This work was supported by a grant from the Major State Basic Research Development Program of China. 
Table II. In vitro antifungal activity of the fusion enzyme.

\begin{tabular}{|c|c|c|c|c|c|c|c|c|c|c|c|}
\hline \multirow[b]{3}{*}{ Pathogen } & \multicolumn{11}{|c|}{ Antifungal activity (\%) } \\
\hline & \multicolumn{5}{|c|}{ Germination } & & \multicolumn{5}{|c|}{ Germ tube elongation } \\
\hline & 0.1 & 1 & 10 & 100 & 150 & $\mu \mathrm{g} / \mathrm{ml}$ & 0.1 & 1 & 10 & 100 & 150 \\
\hline Alternaria alternata & 8 & 23 & 68 & 92 & 100 & & 5 & 34 & 52 & 87 & 94 \\
\hline Alternaria solani & 17 & 27 & 56 & 81 & 93 & & 24 & 57 & 83 & 95 & 100 \\
\hline Fusarium oxysporum & 11 & 45 & 71 & 83 & 91 & & 19 & 53 & 74 & 91 & 100 \\
\hline Magnaporthe grisea & 15 & 38 & 64 & 73 & 83 & & 30 & 67 & 87 & 93 & 99 \\
\hline Verticillium dahliae & 22 & 56 & 89 & 100 & 100 & & 43 & 73 & 93 & 100 & 100 \\
\hline Botrytis cinerea & 16 & 34 & 55 & 68 & 82 & & 25 & 35 & 69 & 84 & 89 \\
\hline
\end{tabular}

The values are means of data from two repetitions of the experiment, with six replicates per treatment.

Balasubramanian N., Juliet G. A., Srikalaivani P., and Lalithakumari D. (2003), Release and regeneration of protoplasts from the fungus Trichothecium roseum. Can. J. Microbiol. 49, 263-268.

Bradford M. M. (1976), A rapid and sensitive method for quantitation of microgram quantities of protein utilizing the principle of protein-dye binding. Anal. Biochem. 72, 248-254.

Carsolio C., Gutierrez A., Jimenez B., Van Montagu M., and Herrera Estrella A. (1994), Characterization of ech-42, a Trichoderma harzianum endochitinase gene expressed during mycoparasitism. Proc. Natl. Acad. Sci. USA 91, 10903-10907.

Chet I. (1994), Biological control of fungal pathogens. Appl. Biochem. Biotechnol. 48, 37-43.

De La Cruz J., Hidalgo-Gallego A., Lora J. M., Benitez T., Pintor-Toro J. A., and Llobell A. (1992), Isolation and characterization of three chitinases from Trichoderma harzianum. Eur. J. Biochem. 206, 859-867.

Flores A., Chet I., and Herrera Estrella A. (1997), Improved biocontrol activity of Trichoderma harzianum by over-expression of the proteinase-encoding gene prb1. Curr. Genet. 31, 30-37.

Freeman G. G. and Morrison R. I. (1949), The isolation and chemical properties of trichothecin, an antifungal substance from Trichothecium roseum. Biochem. J. 44, $1-5$.

Frohman M. A., Dush M. K., and Martin G. R. (1988), Rapid production of full-length cDNAs from rare transcripts: amplification using a single gene-specific oligonucleotide primer. Proc. Natl. Acad. Sci. USA 85, 8998-9002.

Garcia I., Lora J. M., de la Cruz J., Benitez T., Llobell A., and Pintor-Toro J. A. (1994), Cloning and characterization of a chitinase (chit42) cDNA from the mycoparasitic fungus Trichoderma harzianum. Curr. Genet. 27, 83-89.

Hayes C. K., Klemsdal S., Lorito M., Di Pietro A., Peterbauer C., Nakas J. P., Tronsmo A., and Harman G. E. (1994), Isolation and sequence of an endochitinase- encoding gene from a cDNA library of Trichoderma harzianum. Gene 138, 143-148.

Hohn T. M. and Desjardins A. E. (1992), Isolation and gene disruption of the Tox 5 gene encoding trichodiene synthase in Gibberella pulicaris. Mol. Plant-Microbe Interact. 5, 249-256.

Huang H. C. and Kokko E. G. (1993), Trichothecium roseum, a mycoparasite of Sclerotinia sclerotiorum. Can. J. Bot. 71, 1631-1637.

Joffe A.Z. (1974), Toxicity of Fusarium poae and F. sporotrichioides and its relation to alimentary toxic aleukia. In: Mycotoxins (Purchase I. F. H., ed.). Elsevier, Amsterdam, pp. 229-262.

Jones J. D. G., Dunsmuir P., and Bedbrook J. (1985), High level expression of introduced chimaeric genes in regenerated transformed plants. EMBO J. 4, 2411-2418.

Kim D. J., Beak J. M., Uribe P., Kenerley C. M., and Cook D. R. (2002), Cloning and characterization of multiple glycosyl hydrolase genes from Trichoderma virens. Curr. Genet. 40, 374-384.

Kumar S. and Jha D. K. (2002), Trichothecium roseum a potential agent for the biological control of soybean rust. Indian Phytopathol. 55, 232-234.

Laemmli U. K. (1970), Cleavage of structural proteins during the assembly of the head of bacteriophage T4. Nature 277, 680-685.

Li D., Zhang S., Liu K., and Lu J. (2004), Purification and partial characterization of a chitinase from the mycoparasitic fungus Trichothecium roseum. J. Gen. Appl. Microbiol. 50, 35-39.

Lorito M., Woo S. L., Fernandez I. G., Colucci G., Harman G. E., Pintor-Toro J. A., Filippone E., Muccifora S., Lawrence C. B., Zoina A., Tuzun S., and Scala F. (1998), Genes from mycoparasitic fungi as a source for improving plant resistance to fungal pathogens. Proc. Natl. Acad. Sci. USA 95, 7860-7865.

Rod J. (1984), Antagonistic effects of some fungi on fungal pathogens causing storage rot of onion (Allium сера L.). Ceska Mykol. 38, 235-239. 
Schirmbock M., Lorito M., Wang Y. L., Hayes C. K., Arisan-Atac I., Scala F., Harman G. E., and Kubicek C. P. (1994), Parallel formation and synergism of hydrolytic enzymes and peptaibol antibiotics, molecular mechanisms involved in the antagonistic action of Trichoderma harzianum against phytopathogenic fungi. Appl. Environ. Microbiol. 60, 4364-4370.

Sesan T. (1986), A new contribution to the study of the biology of Trichothecium roseum Link and Gliocla- dium roseum Bainier. Stud. Cercet. Biol. Ser. Biol. Veg. 38, 78-82.

Tronsmo A. and Harman G. E. (1993), Detection and quantification of $N$-acetyl- $\beta$-D-glucosaminidase, chitobiosidase, and endochitinase in solutions and on gels. Anal. Biochem. 208, 74-79.

Urbasch I. (1985), Antagonistische Wirkung von Trichothecium roseum (Pers.) Link ex Gray auf Pestalotia funereal Desm. Phytopathol. Z. 113, 343-347. 